\title{
Workplace flexibility and control in temporary agency work
}

\author{
Gunilla Olofsdotter* \\ Department of Social Sciences, Mid Sweden University, Östersund, Sweden
}

\begin{abstract}
This article explores workers' experiences of flexibility, control, and autonomy in organisations with extensive contracting of staff from temporary work agencies (TWAs). The starting point for this article is in theoretical perspectives on workplace flexibility and organisational control practices. I argue that workers' opportunities to control and have autonomy over their work and accomplish workplace flexibility are interconnected with the controlling practices that are present in their everyday working life. In organisations with extensive hiring of temporary agency workers (TAWs), this is complicated further, as workers from different organisations, with different management strategies, are working together at the same work site. Open-ended, semi-structured interviews were conducted with TAWs and regular employees in three user firms with extensive contracting of TAWs. A questionnaire was also completed by them. The results show that there are few opportunities for either TAWs or regular staff to achieve workplace flexibility in terms of making choices about where, when, and for how long they are going to work. The findings contradict assumptions that formal differences between the employment conditions of regulars and agency workers affect their opportunities for workplace flexibility. Similar technical control systems were used in the user firms despite differences between assembly line production and customer support. Despite these similarities in the opportunities for flexibility for both groups of workers, the findings showed some differences between TAWs' and regulars' everyday experiences of flexibility and control. The findings showed how close surveillance by technological systems was intertwined with a normative control, which means the awareness among TAWs of their replaceable position implicates anxiety about the consequences of absence from work. As a consequence of their vulnerable position, TAWs were striving to prove themselves to be competent to both the user firms and the agency. This highlights the dualistic controlling practices that TAWs are subjected to by user firms as well as the agency in their everyday work. This constitutes an effective and powerful system of organisational control.
\end{abstract}

Keywords: Temporary work agencies; technological control; normative control; dualistic control; workplace flexibility; call centre; assembly line

The hiring of staff from temporary work agencies (TWAs) is seen as a viable approach to meet the need for numeri- cal flexibility in user firms (Allvin, Jacobsson, \& Isaksson, 2003, p. 38; Andersson \& Wadensjö, 2004; Atkinson,

^Correspondence to: Gunilla Olofsdotter, Department of Social Sciences, Mid Sweden University, SE-831 82 Östersund, Sweden. Email: gunilla.olofsdotter@miun.se

(C) 2012 G. Olofsdotter. This is an Open Access article distributed under the terms of the Creative Commons Attribution-Noncommercial 3.0 Unported License (http://creativecommons.org/licenses/by-nc/3.0/), permitting all non-commercial use, distribution, and reproduction in any medium, provided the original work is properly cited. 


\section{G. Olofsdotter}

1984; Houseman, 2001; Kalleberg, 2001). However, flexibility in terms of hiring staff is often described as being positive only for employers. Such an assumption is contradicted by, for example, Reilly (1998), who argues that flexibility can be mutually beneficial for both employers and employees. This positive side of flexibility is often highlighted in the marketing campaigns of TWAs in relation to notions of "work when you want, be free when you want" (Garsten, 2008, p. 38). Flexibility is described here as involving a range of opportunities, control over one's working time, and the freedom to make decisions according to one's personal priorities (Garsten, 2008, p. 42). This means that employment in a temporary work agency can give employees opportunities for autonomy and control over their working life. It is therefore important to deepen understandings of "for whom" flexibility can have positive or negative consequences (Furåker, 2007; Furåker, Håkansson, \& Karlsson, 2007; Karlsson, 2007).

This means looking at how flexibility in organisational studies can be conceptualised in two distinct ways: from an organisational perspective and a worker perspective (Hill et al., 2008). From an organisational perspective, flexibility can be described as the degree to which organisational features allow organisations to adapt to changes in their environment, for example, by varying the size of the workforce (Atkinson, 1984; Hill et al., 2008, p. 150). The contracting of staff from TWAs is one way of varying the size and structure of the workforce (Connelly \& Gallagher, 2004; Gallagher \& Sverke, 2005; Houseman, 2001). Flexibility from a worker perspective is about a worker's ability to make choices in their professional life regarding where, when, and for how long work is performed (Hill et al., 2008, p. 151). This means that flexibility is about much more than when to start and end a working day; for instance, it concerns taking time off to take family members to the doctor or visit their children's schools (Eaton, 2003). Nevertheless, it is often the employee who has to adjust to the standards of flexibility set for him or her by the employer. When it comes to temporary agency workers (TAWs), their freedom to choose to accept or even refuse an assignment is most often constrained by their limited access to work opportunities (Garsten, 2008, p. 17). This raises questions whether flexible organisational principles, such as those surrounding agency work, increase employees' control over work or imply a reduced control and autonomy over work, followed by standardisation and surveillance. Therefore, this article focuses on agency workers' and regular workers' experiences of flexibility, control, and autonomy in their everyday work in organisations with extensive contracting of staff from TWAs.

\section{THEORETICAL POINTS OF DEPARTURE}

In analysing flexibility from a worker perspective, this article takes its starting point in theoretical perspectives on workplace flexibility and organisational control practices. I argue that workers' opportunities to control their work, have autonomy over it, and accomplish workplace flexibility are interconnected with the controlling practices that are 
present in their everyday working lives. In organisations with extensive hiring of TAWs, this is even more complicated, as workers from different organisations, with different management strategies, are working together at the same work site.

The opportunities for workers to adjust their working time according to their own needs can be defined as the ability of workers to make choices about "when, where, and for how long they engage in work related tasks" (Hill et al., 2008, p. 152). Flexibility in relation to when work is done often takes the form of schedule flexibility, which allows workers to modify their work schedules (Hill et al., 2008). This can be about flexible working hours, meaning that employees can decide when to influence work schedules and when to begin and end their working day (Boje \& Grönlund, 2003; Reilly, 1998, p. 11). Workplace characteristics, such as organisational cultures that support flexible work policies, are important and influence the degree to which workplace flexibility is achieved (Hill et al., 2008).

In theories of organisational control, a number of strategies are described. First, there are simple control strategies through which managers can directly control their workers. Second, there is bureaucratic control, where supervision rests on rules, formal incentives, and punishments, and where workers learn and follow organisational rules. A third strategy is technological control, for example, an assembly line, in which the machines control the workers and personal surveillance is reduced to a minimum (Edwards, 1979; Gossett, 2006, p. 383; Simpson, 1985). Information technology has changed the nature of work in many occupations and has created new possibilities for management control. Technological monitoring systems can have a considerable influence on control and workers' perceived autonomy over work and working time (Bélanger, 2006). The entire production process can be based on technology that paces and directs the labour process. This means that instead of direct supervision from managers, technology manages the labour process and the workers, for example, matching workers' pace to that of an automated assembly line (Gossett, 2006, p. 383).

However, there are differences in the impact of information technology (IT) between occupations and sectors. Two sectors that are subjected to extensive technical control are assembly line production and call centre work. In routine assembly work, workers' performance is dependent on the quality and the quantity of the daily output of each worker. This means that management control is present in routine assembly work. Nevertheless, although these modes of control may occur in a relatively pure form, organisations may also exert more than one kind of control over different workers (Edwards, 1979; Gossett, 2006).

In call centres, the whole working process is subjected to technological control. Calls are monitored and measured and customer service is standardised (Deery \& Kinnie, 2002). This technical control focuses on "average handling time and time spent off the phone" and can also give information about the way that each worker handles each customer by controlling those programs the worker has used (Bélanger, 2006, p. 341). 


\section{G. Olofsdotter}

Organisations can also use more normative tactics to control their workforce. Such an approach can be labelled as cultural or normative control (Frenkel, Tam, Korczynski, Shire, 1998; Korczynski, 2001). New organisational forms with flattened structures are often incompatible with traditional forms of labour control. Instead, management has developed new modes of controlling and influencing the behaviour of their workers with which they internalise the values and goals of management (Degiuli \& Kollmeyer, 2007). These strategies attempt to foster worker productivity and reduce worker resistance by drawing on the collective and social aspects of the organisation (Gossett, 2006, pp. 382-383). Nevertheless, as Gottfried (1991, p. 699) states, these theories assume that "management establishes control over workers within a work site". In the triangular relationship between TAWs, the TWA, and the user firm, labour control is divided between the two firms. This implies that TAWs are subjected to two sets of management, where bureaucratic control and decentralised mechanisms of control interact. Gottfried (1991, p. 700) describes this as a "dualistic mechanism of control".

The user firm and the agency share a common interest of controlling workers. A dualistic control is about linking together control strategies from both firms, although they might have different goals. The user firm makes a profit from control over the worker's work intensity and the agency's profit is gained from the worker's time at work. This dualistic control works on two levels: (1) on a bureaucratic level, whereby the agency, along with the user firm, secures the
TAW's compliance with the work rules by subjecting the worker to overlapping systems of sanctions; and (2) on a decentralised level, whereby the agency indirectly controls workers (Gottfried, 1991, p. 704). This type of control can be compared to the findings of Degiuli and Kollmeyer (2007). In their study of the Italian temporary work industry, they found that ideological power was crucial for aligning the interests of TAWs with those of the agencies and the user firms. For example, a fear of being fired and replaced with someone else makes it necessary for TAWs to put the maximum amount of effort possible into each assignment, and this makes it hard for them to complain about their working situation (Olofsdotter, 2008, 2012 Degiuli \& Kollmeyer, 2007).

\section{THE TEMPORARY WORK AGENCY SECTOR}

When organisations hire staff from TWAs, employees from different organisations, with differences in terms of employment, are working together, often doing the same tasks (Olofsdotter, 2008). TAWs, like other forms of temporary workers, may have varied skills or educational backgrounds. They may also be working full time or part time and have short-term or long-term employment (Doherty, 2009; Olsen \& Kalleberg, 2004). The diversity of TAWs' personal and work-related characteristics is also reflected in differences in pay, training, and control over work conditions, whereas skilled experts' and professionals' highly valued skills give them benefits and rewards (Kirkpatrick \& Hoque, 2006). 
There are indications of a positive side of agency work in terms of the assumption of a greater "discretion over their scheduling of their working hours" (Coe, Johns, \& Ward, 2009, p. 71). This "freedom of choice" to define and control their own working hours is described as suitable for those individuals who are mainly engaged in parts of life other than paid work and its attached responsibilities (Boje \& Grönlund, 2003; Casey \& Alach, 2004; Garsten, 2008). Temporary agency work is often described as suitable for women's multiple roles as caretakers and workers. There are also indications of workers who only accept assignments that suit them. These are usually people who prefer to work for "social reasons", or for extra money, and so on, and who are not dependent on the income (Garsten, 2008, p. 42).

Nevertheless, TAWs are found to have less favourable working conditions than other employees (Nienhüser \& Matiaske, 2006), and they also have less autonomy and fewer possibilities of influencing holidays, days off, and the pace of work (Letourneux, 1998). There is limited knowledge as to whether these differences are derived from employment status or from differences in age, education, or professional experiences (Nienhüser \& Matiaske, 2006, p. 65). The frequent change of workplaces at different user firms and the duality of employer responsibility can also lead to poor working conditions (Storrie, 2007, p. 115). TAWs are also generally seen as easy to replace and of relatively low value for the hiring organisation (Koene \& van Riemsdijk, 2005; Lepak \& Snell, 1999). Furthermore, employment as a TAW can result in increased vulnerability in the labour market and, in the long run, marginalisation (Boje \& Grönlund, 2003; Krasas Rogers, 1995). These contradictory assumptions about agency work and its ambiguous opportunities for flexibility highlight the complexity of the business and the consequences of employment as a TAW.

In Sweden, TAW is seen as a form of employment which, like other forms of employment, should follow general employment legislation that provides significant protection to all workers, including TAWs (Bergström, 2005; Coe et al., 2009; Knox, 2010; Storrie, 2003b). Collective agreements covering agency workers have emerged in both blue- and white-collar occupations (Bergström Håkansson, Isidorsson, \& Walter, 2007). These collective agreements provide a guaranteed salary to TAWs when they have no assignment of $75 \%-90 \%$ of their usual salary (Knox, 2010; Storrie, 2003b). In principle, there are two different types of employment contracts in Sweden: open-ended contracts and fixed-term contracts. As agency workers in Sweden are treated the same as any other employees on the labour market, their normal employment contract is an open-ended contract (Håkansson \& Isidorsson, 2007).

The TWA sector is relatively small in the Swedish labour market, and it employs approximately $0.8 \%$ of the workforce (Bergström, 2005; Gallagher \& Sverke, 2005; Håkansson \& Isidorsson, 2007; Storrie, 2003b) compared with $1.4 \%$ in the EU as a whole (Storrie, 2003a). The sector is growing in Sweden, and the latest estimated proportion of the working population working in TWAs is $\quad 1.4 \%$ (Swedish-Staffing-Agencies, 2011). The warehouse/industry sector, 


\section{G. Olofsdotter}

a traditional blue-collar sector, is the largest in which TWAs place workers $(34 \%)$ in Sweden. About 23\% work in the office sector. This implies that the largest sectors are concentrated in "the lower skilled and lower paid occupations" (Kirkpatrick \& Hoque, 2006, p. $651)$. Only $1.2 \%$ of staff is placed in call centres. Other sectors are traditional white-collar sectors, for example, finance, IT consulting, healthcare, technology, retail stores, and teaching (Coe et al., 2009).

The overall aim of this article is to explore workers' experiences of flexibility, control, and autonomy in their everyday work in organisations with extensive contracting of staff from TWAs. Do the opportunities for workplace flexibility differ between agency workers and regular workers? Which controlling strategies are present in their everyday work in client organisations? Do the controlling strategies differ between the groups?

I argue that the opportunities to achieve workplace flexibility for agency workers as well as for regular workers are interrelated with organisational control practices. Following theories of workplace flexibility (Hill et al., 2008; Reilly, 1998) and organisational control practices (Gossett, 2006; Gottfried, 1991), the study will illustrate the complexity of workplace flexibility and control in user firms.

The discussion is based on studies in three user firms with extensive contracting of TAWs from several TWAs. Based on a survey and interviews with both TAWs and regular employees, the main emphasis in this article is on TAWs' experiences.

\section{METHOD}

The data reported in this article are part of a larger project that examines issues concerning working conditions, attitudes, and interactions in three user firms with extensive contracting of TAWs: a call centre and two manufacturing firms in telecommunication and engineering. This approach has provided a thorough understanding of the consequences of the structural use of contracting through TWAs as an extended selection and recruitment procedure. The empirical data presented in this article are based on both interviews and a survey answered by TAWs and regular workers employed in the user firms.

A questionnaire was devised and distributed to personnel working in the three user firms (Table I). In production

Table I. Gender, personnel categories in questionnaire (Number; \%, $n=137$ ).

\begin{tabular}{lcccc}
\hline Personnel categories & Production & Call Centre & Mechanic & Total (\%) \\
\hline Regular employees & 9 & 17 & 30 & $56(40.8)$ \\
$\quad$ Men & 3 & 9 & 2 & $14(10.2)$ \\
$\quad$ Women & & & & \\
TAWs & 16 & 6 & 21 & $43(31.4)$ \\
$\quad$ Men & 18 & 38 & 53 & $24(17.6)$ \\
$\quad$ Women & 46 & & $53(100)$ \\
Total & &
\end{tabular}


and the call centre, a questionnaire was distributed in the form of a Web survey to e-mail addresses provided by user firms and TWAs. Since regulars and TAWs in Mechanic did not have access to e-mail at work, the same questionnaire was distributed to them during staff meetings in the form of a traditional paper questionnaire.

The study was carried out during May and June of 2008. The respondents were aged between 18 and 65 . Out of a total of 271 questionnaires, 137 were returned giving a response rate of $51 \%$. Since the gender of everyone in the study was given by the companies, it was possible to compare the gender distribution of the non-response group with the final sample. These analyses revealed that the sample given did not differ significantly from the initial sample in this respect. The study is relatively small scale, therefore conclusions and generalisations relating to a broader organisational population should be treated with caution. Nevertheless, the organisations were strategically chosen to address the consequences of the extensive contracting of TAWs for regulars' and TAWs' working lives.

The main qualitative research was carried out during weekly workplace visits. At each workplace, the initial visit involved conversations and interviews with managers, and they were asked to suggest members of staff and TAWs to be interviewed. Respondents were selected on the basis of factors, such as age, gender, and employment status (regulars and TAWs). The interviews were conducted separately by my colleague and I. In total, 57 interviews were carried out with regulars and TAWs (Table II). The TAWs perform their daily work at the user firms' premises.

The duration of each interview was between 1 and 2 hours and was conducted in conference rooms at the user firms. The interviews were semistructured and designed to gain an understanding about workers' experiences of their working conditions, recruitment, work organisation, flexibility strategies, and their interaction with co-workers. An interview guide was used to ensure a degree of consistency in the process. The interviewees were invited to bring up any issues that they felt were important or relevant to the conversation (Creswell, 2007; Fielding \& Thomas, 2001). A benefit of this approach was that interviewees were able to mention new aspects of their working situation that

Table II. Gender, personnel categories in interviews.

\begin{tabular}{lcccc}
\hline Personnel categories & Production & Call Centre & Mechanic & Total \\
\hline Regular employees & 8 & 7 & 12 & 27 \\
$\quad$ Men & 3 & 0 & 1 & 4 \\
$\quad$ Women & & & & \\
TAWs & 7 & 4 & 0 & 18 \\
$\quad$ Men & 4 & 15 & 20 & 57 \\
$\quad$ Women & 22 & & \\
Total &
\end{tabular}




\section{G. Olofsdotter}

may not otherwise have been considered by us as researchers. The informants were assured of their anonymity and, with the participants' permission, the interviews were tape-recorded and transcribed verbatim.

At the qualitative analysis level, it is important that the researcher becomes familiar with the data. The collected data were analysed to identify themes, concepts, and patterns that might contribute to an understanding of the studied phenomenon (Fielding \& Thomas, 2001, p. 137). After transcription and the first reading of the transcripts, there was a more careful reading of the interviews. The first step was to code the interviews. In connection with a careful reading of the transcripts, concepts or expressions were written in the margin to describe the content. All data were coded for categorical development and reoccurring patterns (Strauss \& Corbin, 1998). The transcripts were coded paragraph by paragraph. The intention was to reduce the data to analytical categories, for example, "control" or "flexibility", or describing categories, for example, describing employment as TAW or regular. The analytical codes generated questions and theoretical connections, while the describing codes gave background information. The next step was to categorise codes about the same phenomenon into themes, thereby reducing the data to smaller units, for example, "ideological control" and "management control" or "influencing working time". This is described as "pattern coding" by Miles and Huberman (1994), p. 69). Then the encoded material was subsequently sorted and added into matrices based on the theoretical concepts, phenomena, and situations.

\section{THE ORGANISATIONS}

The three companies chosen for this research reflect different types of organisations with extensive hiring of TAWs. The first company, Production, is concerned with industrial production in telecommunication. It is a full time, blue-collar workplace. There has been extensive use of TAWs in Production during the major part of the new millennium. No staff were recruited or employed as blue-collar workers during the few years before our study. Approximately half of the blue-collar workforce was working as TAWs at the time of the study. At Production, work in telecommunication is organised as shift work in line production and is controlled by technological systems.

In the second company, Mechanic, the situation is slightly different, although there are similarities between blue-collar work and assembly work. The hiring of staff from TWAs is described as a "trial period of employment". After 6-12 months, the most qualified TAWs might be offered employment at Mechanic. At the time of the study, approximately $20 \%$ of the workforce was hired as TAWs. In Mechanic, work is organised according to an assembly line principle, that is; some operations are managed by robotics and controlled by technological systems.

The third company, the Call Centre, is a white-collar workplace working with telephone support for TV, broadband, and telephone services. The support services at the Call Centre are open almost around the clock, 7 days a week. To keep these hours, the staff are divided into groups with differences in scheduled working hours and wages. Whenever a 
vacancy arises in the Call Centre, TWAs deliver the number of TAWs demanded. No staff is directly recruited by the Call Centre, except in specialised positions or as managers.

The educational level for TAWs and regulars in the three organisations is similar. A total of $70 \%$ of regular employees and $77.6 \%$ of TAWs have between 2 and 4 years' upper-secondary qualifications. As Table III shows, this number implicates that there are no clear distinctions between TAWs and regulars in terms of educational qualifications. This also implies that there are probably no workers or a limited selection of workers are contracted as TAWs in these user firms (Koene \& van Riemsdijk, 2005; Lepak \& Snell, 1999).

The results also show that almost the entire workforce, $97.1 \%$ of regulars and $86.4 \%$ of TAWs, works full time for more than 35 hours per week. Most of the regulars (95.7\%) and TAWs (72.3\%) have open-ended contracts with the user firm or the TWA.

These results give a comprehensive picture of the personal and work-related characteristics of TAWs and regulars working in these three companies. It is a picture of a workforce with a similar educational background from upper-secondary school that is working full time and has permanent employment either in user firms or in TWAs. Based on these results, it would be interesting to know whether TAWs and regulars experience the same opportunities to influence their working hours, breaks and days off (see Coe et al., 2009; Nienhüser \& Matiaske, 2006).

\section{WORKING TIME FLEXIBILITY}

Flexibility from a worker's perspective can be described as the degree to which a worker can choose "where, when, and for how long work is performed" (Hill et al., 2008, p. 151). The questionnaire collected information on the opportunities for flexible working hours from the TAWs' and regulars' points of view. Flexible working hours, or "flexitime", can be described as an arrangement "where employees can decide within limits when to begin and end their work each day" (Jonsson, 2007, p. 205). A question was therefore phrased as: "Are you able to change and adapt your working time according to your own needs?" Figure 1 presents the extent of these opportunities.

Note that chi-square tests comparing TAWs and regulars showed no significant difference between the groups. The most

Table III. Personal and work related characteristics ( $\%, n=137)$.

\begin{tabular}{lcc}
\hline & Regular employees & Temporary agency workers \\
\hline Age (mean) & 35.73 & 28.97 \\
Educational level & & \\
$\quad$ Elementary school & 10.0 & 9.0 \\
Upper secondary school & 70.0 & 77.6 \\
$\quad$ University & 20.0 & 13.5 \\
Working full-time $>$ 35 hours/week & 97.1 & 86.4 \\
Open-ended contracts & 95.7 & 72.3 \\
\hline
\end{tabular}




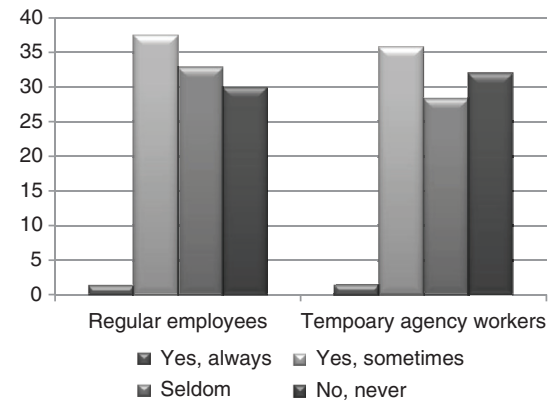

Figure 1. Are you able to change and adapt your working time according to your own needs?

$$
(\% ; n=137) \text {. }
$$

striking result is that almost none of them has answered that they are "always" able to change their working hours according to their own needs. The main part of both groups answered "Yes, at times" and "Seldom". However, 30\% of regulars and $32.1 \%$ of TAWs answered that they can never change their working time.

Flexibility from a worker's perspective can also be about the rights or the opportunities to take a pause from work when the need arises (Jonsson, 2007). Consequently, a question was asked in the survey about TAWs' and regulars' opportunities to leave work for part of the day to perform a private errand (see Figure 2).

Again, the results show a similar distribution of both TAWs' and regulars' opportunities to leave work for part of the day for private matters in all three user firms. Similarly, chi-square tests comparing TAWs and regulars showed no significant difference between the groups. A considerable number of TAWs $(46.3 \%)$ and regulars $(48.3 \%)$ answered that they can leave work sometimes. Nevertheless, the most striking difference between the groups is that

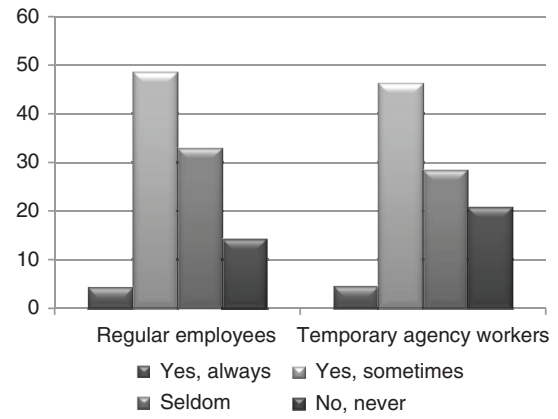

Figure 2. Are you able to leave your work part of the day to perform a private errand? $(\% ; n=137)$.

$14.3 \%$ of regulars, compared to $20.9 \%$ of TAWs, are prevented from leaving work for part of the day to perform a private errand. These results contradict the assumption that work as a TAW should involve control over one's working time and personal priorities, that is, having the opportunities to make choices about where, when, and for how long work is performed (see Hill et al., 2008).

During the interviews, the question of working time flexibility was deepened. Regulars at the Call Centre stated that there are opportunities to change shifts with each other and to make use of working hours that have accrued if they apply for this well in advance. However, this is dependent on the number of incoming calls:

Yes, if it is a "quiet" day and I go and say "could I get some free time?" then it's probably not a problem .... But it may be more stressful if you work weekends and it's just your team who are working weekends, and then you should have asked quite a while before. (Regular, Call Centre) 
This is described in similar ways in all three sectors by both regulars and TAWs. It is difficult for both groups to be absent without either applying for free time well in advance or managing to exchange shifts with each other. However, the triangular relationship between TAWs, the agency, and the user firm means that TAWs have to discuss and apply for some time off from both organisations.

If you want to apply for free time you first have to check with the production manager. If it is $\mathrm{OK}$ with him you will check with the agency. (TAW, Production)

This highlights a work situation in which TAWs are subjected to controlling practices by both the user firm and the temporary work agency. Such control is described by Gottfried (1991) as a dualistic control that links together control strategies from both firms, although the companies might have different goals.

The TAWs who work at the Call Centre describe a work situation in which they sometimes have difficulties in planning and asking for time off in advance because of last-minute changes in their work schedule. These difficulties are also underlined by a TAW at Production, who emphasises that TAWs always have to be prepared to take on new assignments in another user firm, often on short notice: "often monthly and sometimes weekly notice" (TAW, Production).

This statement draws attention to the everyday experiences of being adaptable when working as a TAW. Consequently, these changes in schedules and assignments might be more or less incomp- atible with adjusting working hours according to one's own needs. Collective agreements cover agency workers' terms of employment (Bergström, 2005; Coe et al., 2009; Storrie, 2003b). Despite these rules and regulations, TAWs described some difficulties in making use of the opportunities they are entitled to take in their terms of employment. These difficulties are also recognised and described by one of the regulars in Production:

I do not need to feel anxious about being absent from work. I can just make a call and someone can replace me. But if you are working as a TAW you are supposed to be here. Repeated absence, I have seen it many times, they (TAWs) are replaced, irrespective of reasons.

He continues:

You notice that they (TAWs) are under a lot of pressure .... They know that they have to be exactly on time; if they take too long coffee breaks or come a little too late, it can just be a couple of minutes, they are confronted. They have their eyes on them.

The above quotations illustrate the differences between TAWs and regulars when it comes to an insecurity concerning the consequences of being absent from work or even being a few minutes late. TAWs are subjected to higher pressure than regulars to keep up working hours, and they are subject to an implicit demand for constant attendance so as not to risk losing the assignment. This implies a feeling of insecurity that functions as a normative control that enhances 
TAWs' compliance with demands from both firms (Degiuli \& Kollmeyer, 2007; Frenkel et al., 1998; Korczynski, 2001). A TAW working at Production describes it this way:

Anyone who works as a TAW has to be flexible and able to work anytime and anyhow. You cannot say no. If you say no you might lose your employment.

Such feelings of insecurity are also described by a TAW working at the Call Centre:

Those who are displaced go back to the agency in order to be sent somewhere else. It can be almost any kind of job. If you do not want the job, then you might be dismissed.

As the quotations show, TAWs experience feelings of insecurity about losing their assignment and, in the long run, their employment (see also Olofsdotter, 2008, 2012). Degiuli and Kollmeyer (2007) describe a similar situation in their study of the Italian temporary help industry, where the feeling of insecurity among TAWs made it hard for the workers to complain about their work situation. Degiuli and Kollmeyer (2007) found that ideological power played significant roles in "aligning the perceived interests of temporary workers with those of temporary agencies and their client companies" (Degiuli \& Kollmeyer, 2007, p. 511). This means that TAWs are subjected to a "dualistic mechanism of control", as described by Gottfried (1991, p. 700), through which the agency and the user firm share a common interest of controlling workers to secure TAWs' compliance with work rules.
In summary, the questionnaire showed small differences between TAWs and regulars in terms of their opportunities to achieve working time flexibility. However, when analysing the interviews, some differences occurred that might derive from the controlling strategies apparent in both organisations. It is obvious that TAWs are subjected to a normative and dualistic control. This means that a fear of losing their assignment and, in the long run, their employment makes it more difficult for TAWs than regulars to make demands of working time flexibility.

\section{TECHNOLOGICAL CONTROL}

The performance of all workers is controlled by technological systems in all three user firms. In the Call Centre, all calls are monitored and measured, for example, time spent on the phone and average handling time (see Bélanger, 2006; Olofsdotter, 2012). A situation of constant surveillance might be stressful. A TAW at the Call Centre describes it like this:

Interviewer: How does it feel to be under surveillance?

TAW: You have to stop thinking about it, otherwise you will become stressed out. But it is always at the back of one's head.

Interviewer: But you receive feedback?

TAW: Once a week, and statistics every day.

He continues to describe how the managers follow-up the statistics with quarterly individual conversations. However, the technological control is also accompanied by management control, which means that calls and time spent off 
the phone are monitored directly by managers:

If you have been sitting for too long after a call without taking on a new call, then you might hear it [instruction via their headphones to take another call] directly. There is always someone responsible for controlling times for each case in real time. If you are sitting down for too long [between calls] they can say: what are you doing? Go in and take calls again. (TAW, Call Centre)

When the pressure is high with incoming calls, it only takes approximately 7-8 minutes between calls before traffic control requests workers to take on new calls. But what happens if a worker has to leave for a few minutes to visit the bathroom?

Then you will have to say it. And it might be OK. But they have still shown that they have control. It is like a self-censorship and that is what they are hoping for. (TAW, Call Centre)

This means that management control is present and intertwined with technological control in everyday work at the Call Centre. These controlling practices are the same for both TAWs and regulars, but TAWs seem to be more worried about the surveillance and the statistics relating to their performance than regulars.

They [TAWs] talk a lot about these things, like "How many calls have you answered?", that is, these handling times. There is a difference, where TAWs are trying to manage it better than those who have been working here for a long time and who feel more secure in their employment. (Regular, Call Centre)
In Production, the production process is organised in lines where each worker assembles one or several components before it is sent to the next worker. Work is stressful and controlled by technological systems that allow workers to scan start and stop times for each product on the assembly line. This makes it possible to control the exact time for putting each product together. One of the regulars at Production says that TAWs often force up the pace on the assembly line in an effort to show themselves as competent. As Degiuli and Kollmeyer (2007) state, to avoid the perils of temporary work, TAWs are encouraged to exert their best effort on each assignment.

Another regular works on an assembly line that should take 4 minutes from start to finish. She describes her work as stressful when everything is working as it should but sometimes interruptions are welcome:

Regular: It is good if everything is not working as it should. Then you may have some small breathing space and you can go to the lavatory. When everything is rolling there is no time ....

Interviewer: What happens if you run to the lavatory when it is rolling?

Regular: Then I may have two units waiting when I come back. Or you will have to stop the assembly line, but it will be noticed at once. Then we will have to explain; at the smallest disturbance we will have to note what has caused the disturbance and at what time. If you cannot explain why we cannot meet the goals, then you are in trouble.

The situation is similar at Mechanic, where the production process is also 


\section{G. Olofsdotter}

monitored by technological controlling systems. The interviews showed some doubt over management's trust in statistics when deciding which agency workers will be staying on and which will be leaving their assignment.

Then they receive a list of everyone. So if they have to send four people home they just look at the last four rows and send them home. And it might be very small differences; I have maybe done $1 \%$ less compared to the one who stays. (TAW, Mechanics)

The quotation shows how management uses technological control as a way of controlling the work intensity (Gossett, 2006; Gottfried, 1991) and as a means of choosing the "right" co-workers. This also points to the appearance of dualistic controlling practices (Gottfried, 1991). Technological control in user firms is intertwined with a normative control (Degiuli \& Kollmeyer, 2007; Frenkel et al., 1998), which means TAWs are afraid of not performing up to standard. A regular at Production describes it this way:

Regular: As a regular you do not care as much. If you are a TAW and not keeping up the pace you will be replaced. I have heard from TAWs that they are really afraid of losing their work. So they are more stressed.

Interviewer: Are they working faster?

Regular: Yes, absolutely. I heard that the firm has different TWAs on separate lines, so that they are competing with each other.

This means that TAWs are subjected to dualistic controlling practices from the user firm as well as from the agency.
There are also indications that Production even imposes competition between TAWs from different agencies to find out which line is the most productive. Such a controlling strategy implies that user firms are making the most of the possibilities offered by technological systems. In addition to controlling performance at an individual level, they are also controlling and comparing performance between groups, that is, between groups of workers from different agencies. This also indicates that they are searching for the agency that offers the most eager and compliant workers.

\section{CONCLUDING DISCUSSION}

This study demonstrates the complexity of controlling practices in firms with extensive use of agency workers and how possibilities for workplace flexibility are intertwined with organisational control practices.

The results show that there are few opportunities for either TAWs or regular staff to achieve workplace flexibility in terms of the ability to make choices about where, when, and for how long they are going to work (Hill et al., 2008). Both groups found it difficult to influence working hours and to temporarily leave work to attend to a private matter. Similar technical control systems were used in the three user firms, despite differences between assembly line production and customer support. The findings contradict assumptions that formal differences between the employment conditions of regulars and agency workers affect their opportunities for workplace flexibility. Nevertheless, there are some differences between TAWs' and regulars' 
opportunities to make use of flexible working hours. The workers in the user firms describe the close surveillance by technological systems and how this leads to what a TAW at the Call Centre describes as "self-censorship". This can be understood as a normative control (see Degiuli \& Kollmeyer, 2007; Frenkel, Korczynski, Donoghue, \& Shire, 1995; Rosenthal, 2004), meaning that the awareness among TAWs of their replaceable position implicates a more or less explicit anxiety about the consequences of absence or an application for time off. The more vulnerable position of a TAW means that they are striving to present a positive impression of themselves to both user firms and the TWA. As a consequence, it is difficult to make demands for more individualised working hours. These findings highlight the dualistic controlling practices of both user firms and the agency that the TAWs are dealing with in their everyday work and that these practices constitute effective and powerful systems of organisational control.

\section{CONFLICT OF INTEREST AND FUNDING}

There is no conflict of interest among the authors.

\section{ACKNOWLEDGEMENTS}

The study was funded by the Swedish Council for Working Life and Social Research.

\section{REFERENCES}

Allvin, M., Jacobsson, A., \& Isaksson, K. (2003). Att avgränsa det gränslösa sjuksköterskearbetet. En intervjustudie om sjuksköterskors villkor och valmöjligheter $i$ bemanningsbranschen. (Delimiting endless nursing work. An interview study about the terms and choices for nurses in Temporary Work Agencies). Solna: The National Institute of Working Life.

Andersson, P., \& Wadensjö, E. (2004). Hur fungerar bemanningsbranschen? (How does the Temporary Agency sector work?) in Rapport 2004: 15. Uppsala: IFAU - The Institute for Evaluation of Labour Market and Education Policy.

Atkinson, J. (1984). Manpower Strategies for Flexible Organisations. Personnel Management, 16, 28-31.

Bélanger, J. (2006). Technology and work. In M. Korczynski, R. Hodson, \& P. Edwards (Eds.), Social theory at work (pp. 325-355). Oxford: Oxford University Press.

Bergström, O. (2005). Temporary Work Agencies and Labour Market Policy. In T. Bredgaard, \& F. Larsen (Eds.), Employment policy from different angles (pp. 365-389). Copenhagen: DJOF.

Bergström, O. Håkansson, K. Isidorsson T., \& Walter, L. (Eds.). (2007). Den nya arbetsmarknaden - Bemanningsbranschens etablering $i$ Sverige. (The New Labour Market - The Temporary Work Agency Sector's establishment in Sweden). Lund: Academia Adacta AB.

Boje, T.P., \& Grönlund, A. (2003). Flexibility and employment insecurity. In T.P. Boje, \& B. Furåker (Eds.), Post-industrial labour markets. Profiles of North America and Scandinavia (pp. 186-212). London: Routledge.

Casey, C., \& Alach, P. (2004). "Just a temp?" Women, temporary employment and lifestyle. Work, employment and society, 18(3), 459-480.

Coe, N.M., Johns, J., \& Ward, K. (2009). Managed flexibility. European Urban and regional studies, 16, 65-85.

Connelly, C.E., \& Gallagher, D.G. (2004). Emerging trends in contingent work research. Fournal of management, 30, 959-983.

Creswell, J.W. (2007). Qualitative inquiry $\&$ research design. Choosing among five 
approaches (2nd ed.). Thousands Oaks, NY: Sage.

Deery, S., \& Kinnie, N. (2002). Call centres and beyond: a thematic evaluation. Human Resource Management fournal, 12, 3-13.

Degiuli, F., \& Kollmeyer, C. (2007). Bringing Gramsci back in: labor control in Italy's new temporary help industry. Work, Employment \& Society, 21(3), 497-515.

Doherty, M. (2009). When the working day is through: the end of work as identity? Work, Employment E Society, 23, 84-101.

Eaton, S.C. (2003). If you can use them: flexibility policies, organizational commitment, and perceived performance. Industrial Relations: A fournal of Economy and Society, 42, 145-167.

Edwards, R. (1979). Contested terrain: the transformation of the workplace in the twentieth century. New York, NY: Basic Books.

Fielding, N., \& Thomas, H. (2001). Qualitative interviewing. In N. Gilbert (Ed.), Researching social life (2nd ed., pp. 123-144). London: Sage.

Frenkel, A., Tam, M., Korczynski, M., \& Shire, K. (1998). Beyond bureaucracy? Work organisation in call centres The International fournal of Human Resource Management, 9.

Frenkel, S., Korczynski, M., Donoghue, L., \& Shire, K. (1995). Re-constituting work: trends towards knowledge work and infonormative control. Work, Employment E Society, 9(4), 773-796.

Furåker, B. (2007). Type of employment contract and attitudes to flexibility: an analysis of data from three Swedish surveys. In B. Furåker, K. Håkansson, \& J.Ch. Karlsson (Eds.), Flexibility and stability in working life (pp. 173-196). New York, NY: Palgrave Macmillan.

Furåker, B., Håkansson, K., \& Karlsson, J.Ch. (2007). Reclaiming the concept of flexibility. In B. Furåker, K. Håkansson, \& J.Ch. Karlsson (Eds.), Flexibility and stability in working life (pp. 1-17). New York, NY: Palgrave Macmillan.

Gallagher, D.G., \& Sverke, M. (2005). Contingent employment contracts: are existing employment theories still relevant?
Economic and industrial democracy, 26, 181-203.

Garsten, C. (2008). Workplace Vagabonds. Career and community in changing worlds of work. Chippenham: Palgrave Macmillan.

Gossett, L.M. (2006). Falling between the cracks. Control and communication challenges of a temporary workforce. Management Communication Quarterly, 19(3), 376-415.

Gottfried, H. (1991). Mechanisms of control in the temporary help service industry. Sociological Forum, 6, 699-713.

Hill, J.E., Grzywacz, J.G., Allen, S., Blanchard, V.L., Matz-Costa, C., Shulkin, S., \& Pitt-Catsouphes, M. (2008). Defining and conceptualizing workplace flexibility. Community. Work \& Family, 11, 149163.

Houseman, S.N. (2001). Why employers use flexible staffing arrangements: evidence from an establishment survey. Industrial and Labour Relations Review, 55, 149-170.

Håkansson, K., \& Isidorsson, T. (2007). Flexibility, stability and agency work: a comparison of the use of agency work in Sweden and the UK. In B. Furåker, K. Håkansson, \& J.Ch. Karlsson (Eds.), Flexibility and stability in working life (pp. 123-147). New York, NY: Palgrave Macmillan Ltd.

Jonsson, D. (2007). Time-related flexibility and stability for employees. In B. Furåker, K. Håkansson, \& J.Ch. Karlsson (Eds.), Flexibility and stability in working life (pp. 197-217). New York, NY: Palgrave Macmillan Ltd.

Kalleberg, A. (2001). Organizing flexibility: the flexible firm in a new century. British fournal of Industrial Relations, 39(4), 479-504.

Karlsson, J.Ch. (2007). For whom is flexibility good and bad? An overview. In B. Furåker, K. Håkansson, \& J.Ch. Karlsson (Eds.), Flexibility and stability in workning life (pp. 18-29). Basingstoke: Palgrave MacMillan.

Kirkpatrick, I., \& Hoque, K. (2006). A retreat from permanent employment? Work, Employment E Society, 20, 649-666.

Knox, A. (2010). Lost in translation': an analysis of temporary work agency em- 
ployment in hotels. Work, Employment $\mathbb{E}$ Society, 24(3), 449-467.

Koene, B., \& van Riemsdijk, M. (2005). Managing temporary workers: work identity, diversity and operational HR choices. Human Resource Management Fournal, 15(1), 76-92.

Korczynski, M. (2001). The contradictions of service work: call centre as customeroriented bureaucracy. In A. Sturdy, I. Grugulis, \& H. Willmott (Eds.), Customer service: empowerment and entrapment (pp. 79-101). Basingstoke: Palgrave.

Krasas Rogers, J. (1995). Just a temp. Experience and structure of alienation in temporary clercical employment. Work and Occupations, 22, 137-166.

Lepak, D.P., \& Snell, S.A. (1999). The human resource architecture: toward a theory of human capital allocation and development. Academy of Management Review, 24(1), 31-48.

Letourneux, V. (1998). Precarious employment and working conditions in Europe. Dublin: European Foundation for the Improvement of Living and Working Conditions.

Miles, M.B., \& Huberman, A.M. (1994). Qualitative data analysis: an expanded sourcebook (2nd ed.). Thousands Oaks, CA: Sage.

Nienhüser, W., \& Matiaske, W. (2006). Effects of the 'principle of non-discrimination' on temporary agency work: compensation and working conditions of temporary agency workers in 15 European countries. Industrial Relations fournal, 37, 64-77.

Olofsdotter, G. (2008). Flexibilitetens främlingar: om anställda $i$ bemanningsföretag. [Strangers of flexibility: about Temporary Agency Workers] Sundsvall: Doctoral Thesis, 47. Department of Social Sciences: Mid Sweden University.

Olofsdotter, G. (2012). “'The Staircase Model' - labor control of temporary agency workers in a Swedish call center". Nordic fournal of Working Life Studies, 2(1).

Olsen, K.M., \& Kalleberg, A.L. (2004). Non-standard work in two different employment regimes: Norway and the United States. Work, Employment $\mathcal{E}$ Society, 18(2), 321-348.

Reilly, P.A. (1998). Balancing flexibility meeting the interests of employer and employee. European fournal of Work and Organizational Psychology, 7(1), 7-22.

Rosenthal, P. (2004). Management control as an employee resource: the case of frontline service workers. Fournal of Management Studies, 41, 601-622.

Simpson, R.L. (1985). Social control of occupations and work. Annual Review of Sociology, 11, 415-436.

Storrie, D. (2007). Temporary agency work in the European Union - economic rationale and equal treatment. In B. Furåker, K. Håkansson, \& J.Ch. Karlsson (Eds.), Flexibility and stability in working life (pp. 103-122). New York, NY: Palgrave Macmillan Ltd.

Storrie, D. (2003a). Conclusions: contingent employment in Eurpoe and the flexibilitysecurity trade-off. In O. Bergström, \& D. Storrie (Eds.), Contingent employment in Europe and the United States (pp. 224-247). Cheltenham: Edward Elgar.

Storrie, D. (2003b). The regulation and growth of contingent employment in Sweden. In O. Bergström, \& D. Storrie (Eds.), Contingent employment in Europe and United States (pp. 79-106). Cheltenham: Edward Elgar.

Strauss, A., \& Corbin, J. (1998). Basics of qualitative research. Techniques and procedures for developing grounded theory (2nd ed.). Thousands Oaks, CA: Sage.

Swedish-Staffing-Agencies. (2011). Antal anställda och penetrationsgrad i bemanningsbranschen 2011. (The number of employees and the level of penetration in the Temporary Work Agency sector.) [Online forum comment]. Retrieved from http://www.bemanningsforetagen. se/sa_har_funkar_branschen/fakta_om branschen/9db1c872-0d96-4d44-bfec-ef7 ec0cd816a_2 